\title{
"Some Reflections upon the True Grounds of Morality"-Catharine Trotter in Defence of John Locke
}

\author{
Emilio Maria De Tommaso \\ University of Calabria
}

\begin{abstract}
Although excluded from the standard account of the history of philosophy, Catharine Trotter Cockburn (1679-1749) avoided the 17th-century bias against female intellectual skills and was an active contributor to the early modern philosophical discourse. In her Defence of Mr. Locke's Essay (1702), she defended Locke from several criticisms by Thomas Burnet (1635-1715). By analysing three of Burnet's main arguments, such as the theory of natural conscience, his anti-voluntarism, and his belief in the immateriality of the soul, Trotter showed that he often misinterpreted John Locke’s principles, especially those concerning his moral epistemology. Moreover, beyond her apologetic aim, she also presented her own moral philosophy, arguing that the true ground of morality is the rational and social nature of human beings. Although Trotter was clearly inspired by John Locke, her Defence was not simply a vindication, and she was not his mere handmaiden, for her thought was original and independent in many respects.
\end{abstract}

Keywords: ethics, Trotter Cockburn, John Locke, women philosophers

\section{Introduction}

Between 1697 and 1699, three series of anonymous Remarks upon an Essay Concerning Humane Understanding were published in London, challenging John Locke's epistemology and moral philosophy. The anonymous Remarker was the well-known English theologian Thomas Burnet (1635-1715), author of an impressive cosmogonical work, entitled Sacred Theory of the Earth (1681-1690). ${ }^{1}$ Locke almost ignored those anonymous Remarks, and limited himself to a brief and contemptuous Answer to the first series, appended to his more detailed Reply to the Bishop of Worcester's Answer to his Letter of 1697 (WJL III, 186-9). He charged his adversary with hypocrisy, and blamed him for anonymity: "I should not think it fit—Locke caustically commented - to trouble myself about the questions of a man, which he himself does not think worth the owning” (WJL III, 189).

However, Burnet's remarks caught the attention of Catharine Trotter (1679-1749), a young learned lady, known as a playwright at that time, who wrote a Defence of Mr. Locke's Essay of Human Understanding, and decided to publish it anonymously in 1702. She judged the Remarker's reasons so weak that she "could not doubt of vanquishing him" (WCC II, 155), and she described her adversary as "a caviller” (WCC I, 45) and one of those "who having with much pains imbibed the opinions of reverenced authors, are unwilling to unlearn all their former knowledge, to examine what they have been taught for first principles, not to be questioned, and

Emilio Maria De Tommaso, Ph.D., Department of Humanities, University of Calabria, Italy; main research field: History of Philosophy, Ethics, and Women Philosophers. 
lay aside their sacred ipse dixit” (WCC I, 51). Moreover, Trotter charged him with advisedly misunderstanding Locke's principles, and hence drawing "wrong inferences," "uncertain conclusions, and groundless suppositions” (WCC I, 111).

In this paper, I will outline some of her "reflections upon the true grounds of morality" (WCC I, 49), which she developed in response to Burnet's main objections against Locke. In detail, I will consider the following three points in the Remarker's argument and Trotter's respective replies: (1) Burnet's doctrine of "Natural Conscience," opposed to Locke’s anti-innatism, which Trotter faced with her idea of "Human nature.” understood as rational and sociable; (2) Burnet's accusation of voluntarism against Locke, and Trotter's anti-voluntarist interpretation of Locke's moral philosophy; (3) Burnet's worries concerning both the nature of the soul and the possibility of "Thinking Matter," which Trotter rebuffed by showing that Burnet's own view on this point had problematic consequences for morality.

\section{On Trotter's Defence of Locke}

Although the Defence was initially misattributed to John Locke, its actual authorship was soon known, and, interestingly, this did not prejudice readers against Trotter's thought. On the contrary, some of the most influential philosophers of that time sincerely appreciated her work, ${ }^{2}$ and the fact that Thomas Birch (1705-66), an esteemed historian and biographer of that time, was the editor of her Works and her official biographer is also significant. ${ }^{3}$

Nevertheless, Catharine Trotter has been left out of the canon of the history of western philosophy, as well as a number of other early modern women philosophers, such as Anne Conway, Damaris Cudworth Masham, and Mary Astell. As a consequence of the process of "purification of Philosophy," as defined by Eileen O'Neill, ${ }^{4}$ when mentioned, these learned Ladies were at best labelled as mere handmaidens of the thinkers they were most familiar with. Fortunately, recent studies have revalued their philosophical contributions. ${ }^{5}$ In what follows, I will try to give further evidence of Trotter's acumen, arguing that her moral philosophy was in many respects original despite being strictly related to John Locke’s epistemology.

In the "Letter to the Excellent Mr. Locke," at the beginning of her Defence, she described his Essay Concerning Human Understanding as "a public concern, which everyone has a right and interest to defend" (WCC I, 45). Although "it came too late into the world to be received without opposition," it was an excellent means "to break in upon this sanctuary of vanity and ignorance" (WCC I, 46) that schoolmen had grounded on an "unintelligible jargon" and on the "vain pretence to knowledge of things out of the reach of human understanding” (WCC I, 45). Thus, she felt the urge to defend Locke's precious work against schools authoritarianism, for the sake of truth. Indeed, as she explained, "so hard it is for men, who have been used to receive truth in a particular dress, to know her, when stript of those false colours and borrowed ornaments, with which she is too often disguised" (WCC I, 48).

Trotter occasionally alluded to the weakness of her Defence and the disproportion between her philosophical abilities and those of John Locke. According to Jessica Gordon-Roth, her humble tone shows that, although Trotter felt compelled to defend the Essay, she also felt "ill equipped to undertake the task," and "she grossly underestimated herself." Nevertheless, politeness and humility were formal features of the writing style of that time, very common both in private correspondences and, a fortiori, in public letters-and Trotter usually adopted this style in her epistles. ${ }^{7}$ In my view, aside from formalities, Trotter was deeply aware of her intellectual capabilities and the strength of her own reasoning. Unfortunately, because of the bias against 
women, she lucidly resolved to conceal herself, for the sake of truth only. Indeed, as she explained to Thomas Burnet of Kemnay, "a woman's name would give a prejudice against a work of this nature; and truth and reason have less force, when the person, who defends them, is prejudged against” (WCC II, 155).

While her respect for John Locke was no doubt deep and sincere, ${ }^{8}$ it is also clear that she did not feel inferior to the Remarker. Plainly, it seems to me that she did not feel ill equipped to undertake the task, and did not underestimate herself at all.

\section{Natural Conscience vs. Human Nature}

To begin, Burnet expressed serious doubt on Locke’s epistemology as a sure foundation of morality:

Your general principle of picking up all our knowledge from our five senses, I confess does not fit easily in my thoughts, though you join reflection to help us... As to morality, we think the great foundation of it is, the distinction of good and evil, virtue and vice, turpis \& honesti, as they are usually called: and I do not find that my eyes, ears, nostrils, or any other outward sense, make any distinction of these things, as they do of sounds, colours, scents, or other outward objects. (FR, 4-5)

On the contrary, according to Trotter, there has been "no philosopher before Mr. Locke, that has fixed morality upon so solid a foundation, as he gives many hints of in that Essay" (WCC I, 48). And such foundation is exactly his epistemology, for "I cannot find... that we have any one idea not derived from sensation and reflection” (WCC I, 53). Moreover, from Trotter's perspective, Burnet resolved Locke's epistemology into sensation only, without considering reflection sufficiently. ${ }^{9}$ Indeed, in the whole series of Burnet's Remarks, reflection was implicitly regarded as a sort of secondary instrument of knowledge.

Although knowledge was not "the business of his letter," such a premise has substantial repercussions on Thomas Burnet's inquiry into "a sure foundation of morality" (FR, 4). It is particularly evident from the passage above that, according to the Remarker, the distinction of good and evil was "the great foundation of morality," and such a distinction was understood as "immutable," "intrinsic" to the nature of things, "sudden without any ratiocination, and as sensible and piercing, as the difference I feel from the scent of a rose and of assa-foetida" (FR, 5). Accordingly, in his Third Remarks, Burnet challenged Locke's anti-innatism with his notion of "natural conscience," which particularly caught Trotter's attention. According to Burnet, if practical principles are understood as distinct ideas and propositions, "we do not hold innate principles in that sense" (TR, 6). He accused Locke of exaggerating the matter intentionally, assuming a too rigid idea of knowledge, and ignoring "those natural impressions, which indeed compared with perfect knowledge, are but general, obscure, and indistinct notices, and yet sufficient for the purposes to which they are designed" (TR, 7). For example, a child can feel the difference between bitter and sweet even though he has no distinct idea of sweetness and bitterness. Burnet indeed argued that there is a "sense" or "instinct" which operates within us before reason, and which is "a principle of action" to us. Although it is like a rough diamond, which needs to be polished to "receive further lustre," this instinct is clearly innate, and, as regards morality, it is called "natural conscience:" "I understand-Burnet says—by natural conscience, a natural sagacity to distinguish moral good and evil, or a different perception and sense of them, with a different affection of the mind arising from it; and this so immediate as to prevent and anticipate all external laws, and all ratiocination” (TR, 7-8).

In this notion of natural conscience, there are clear Cambridge Platonist resonances. ${ }^{10}$ In fact, in the Treatise of Freewill, Cudworth had argued that natural love and desire of good and happiness traverse the human soul, "actuating and provoking it continually." He described such love as "a certain vaticination, presage, 
scent, and odour of one summum bonum," which is necessary, immutable, and "always continues the same, in equal quantity." 11 Furthermore, the Remarker's hypothesis of natural conscience somehow echoes another well-known Cambridge Platonist, i.e., Henry More, who, in An Antidote against Atheism, had argued that "the soul of man is not abrasa tabula," but it has "the actual knowledge of eternal truths in her," pointing out that this actual knowledge is not "a certain number of ideas" in our minds, but "an active sagacity in the soul."12 In the Enchiridion Ethicum (1667), More also had maintained that, in the Aristotelian moral philosophy, the right reason was resolved into "an inward sense, or an inward faculty of divination... by which a man might judge of that which in everything were the best” (1690, I, iii, §8, 17). This was what More named "the boniform faculty of the soul: namely, a faculty of that divine composition, and supernatural texture, as enables us to distinguish not only what is simply and absolutely the best, but to relish it, and to have pleasure in that alone" (1690, I, ii, $\S 5,6)$. Such inward sense is a "natural sagacity" of the soul, anticipating any reasoning, and it is "the most divine thing within us” (1690, I, iii, §§7-8, 17). ${ }^{13}$

Similarly, according to Burnet, natural conscience "is seated in the soul of man," and it is the power "of distinguishing one thing from another in moral cases" (TR, 8). He also emphasised that "as our outward senses are sufficient (without distinct ideas and propositions) to give us notice of what is convenient or inconvenient to the body," so our inward sense is "designed to direct us as to what is agreeable or disagreeable, good or hurtful to the soul” (TR, 9). ${ }^{14}$ Furthermore, like Cambridge Platonists, Burnet held that moral virtues and truths are as clear, eternal, and unalterable as mathematical truths:

Let us take a proposition in mathematics, and another in morality: suppose, in the former, that which is often made use of, that the three angles of a triangle are equal to two right ones: and in morals, that it is a wicked thing for a man maliciously to kill his friend, or his father, or any innocent person. The truth of this seems to me as clear, eternal, and unalterable, as the other. (SR, 26)

In the Defence, Catharine Trotter contested Burnet's hypothesis that we can "perceive the morality or immorality of things without any ratiocination," noting that moral virtues, such as justice, fidelity, or gratitude, would be only empty notions, if taken with no relation to human beings. She explained her point of view, by reversing Burnet's comparison between moral and mathematical propositions:

I desire - she argued — any one, to try, whether he can conceive it to be an eternal truth, that it is a wicked thing, for a man to kill his father, or his friend, though there had never been, or designed to be such a thing as friend, father, or man. But whether he can or not, it will still be a truth as certain and immutable, as any proposition in mathematics. No mathematician, that I know of, thinks it necessary to establish the immutability of this truth, that the three angles of a triangle are equal to two right ones; to affirm, that it is true, without any relation to angles or triangles. (WCC I, 55-56) ${ }^{15}$

By natural conscience, Thomas Burnet intended both an innate principle, by which human beings immediately perceive the difference between moral good and evil, and "a rule or direction to our actions" (TR, 9). In other words, he identified the true foundation of morality with this inward sense, anticipating any ratiocination, and, at the same time, he contrasted Locke's moral anti-innatism with the belief in fixed, eternal, and unalterable moral truths. He argued that the knowledge of virtues, such as gratitude, fidelity, and justice, "is not like a theorem, which we come to know by the help of precedent demonstrations and postulatums, but it raises as quick as any of our passions" (FR, 5).

Evidently, Burnet used the term "natural" in reference to both conscience and good and evil, but in two different meanings. As regards good and evil, despite his vague hint at "another order and character," it seems 
to me that "natural" excludes any necessary connection to human morality. On this point, Trotter objected that good and evil, far from being absolute principles implanted by God in our minds from the beginning, are rather ideas formed in us in reference to pleasure and pain. ${ }^{16}$ As a matter of fact, "all moral good-she claimed-consists in doing, willing, or choosing, for oneself or others, whatever is a natural good; and all moral evil, in doing, willing, or choosing whatever is a natural evil, to oneself or others” (WCC I, 57). Interestingly, the word "natural" here emphasises the strict relation between morality and human nature, and Trotter made use of the term advisedly, in order to show how "loose and undetermined" Burnet's language was (WCC I, 100):

Throughout this whole discourse, the Remarker uses indifferently, as terms of the same signification, law of nature, natural conscience, innate principles, innate powers, and natural principles, which all signify very different things; and of which Mr. Locke has only denied innate principles; which considered, it will appear, that he is very little concerned in the greatest part of this dispute. (WCC I, 97)

Trotter also pointed out that, although Locke refused metaphysical or moral truths originally imprinted on the mind, he "does not deny, that there is a power in the soul of perceiving, and assenting to those truths, or of distinguishing good and evil." Simply, she explained, this power does not work "without employing his faculties about it, or without ratiocination" (WCC I, 98), for, on the contrary, it is a consequence of a previous ratiocination, or instruction, which is so immediate that it seems to prevent it, "though it is really an effect of it." This sudden affection in moral cases is what Trotter called "conscience," which "is indeed of excellent use, when it is once set on work by an enlightened judgment, to keep up the distinction of good and evil... and thus may be truly called the support of natural religion; [...] but must not therefore be taken for the law itself, or as the Remarker calls it, the foundation of natural religion” (WCC I, 101). She had probably in mind Locke's definition of conscience as "nothing else, but our own opinion or judgment of the moral rectitude or pravity of our own actions" (WJL I, 38). Far from being an inward moral sense, this opinion comes from sensation and reflection, and, since it is set on work by man's first persuasions and confirmed by his habits, it can neither be proof of innate moral rules, nor the true foundation of morality.

For no doubt-Trotter claimed - there are too many, who by an unhappy early education, pursue with the same bent of conscience, or without the least remorse, what others (who have been better taught) abhor. Now in this case, to bid these men appeal to their consciences, as an innate guide, that will infallibly direct them in their duty, can only serve to confirm them in their prejudices. (WCC I, 102)

Nevertheless, a man of this kind is not condemned to eternal immorality, but he can by "reflection and reason be corrected, and convinced of the natural obligations, which the Creator has laid on him, as a rational, sociable, and dependent creature” (WCC I, 103).

In short, in Trotter's moral philosophy, the grounds of morality are not the original and absolute moral principles in God's mind, but our own nature. Certainly, God is the perfect being, and the moral attributes of goodness and justice are in him, but they are "infinitely beyond the reach of our narrow capacities," and "we could have no idea of them at all without reflection upon ourselves; for whatever is the original standard of good and evil, it is plain, we have no notion of them but by their conformity, or repugnancy to our reason, and with relation to our nature" (WCC I, 57-58). Thus, we first have a notion of good, and then we know that God himself is good. In other words, "it must be by reflecting upon our own nature, and the operations of our minds, that we come to know the nature of God; which therefore cannot be to us the rule of good and evil” (WCC I, 58). 
However, as noted by Patricia Sheridan, there are traces of Trotter's infidelity to Lockean view. On the one hand, she adhered to Locke's epistemology and to his view that, although we have no innate idea of God, we are capable of certain knowledge of God's existence by reflecting upon ourselves. ${ }^{17}$ On the other hand, she ignored that Locke viewed "the normativity of the natural law as consisting in its divine authorship." ${ }^{18}$ In his Essays on the Law of Nature, Locke affirmed that "there is a rule of morals, or law of nature,"19 which is "the decree of the divine will discernible by the light of nature,"20 and "this law does not depend on an unstable and changeable will, but on the eternal order of things." ${ }^{21}$ According to Sheridan, Trotter "was at least selective in her view of what was most worth defending in Locke’s Essay,"22 and she adopted a more anthropocentric view of morality than Locke's. In fact, Catharine Trotter explained that "the Author of our being does require those things of us, to which he has suited our nature, and visibly annexed our happiness, which he has made the necessary motive of all our actions” (WCC I, 58). Thus, since God is our creator and has fitted everything to its proper end — which is happiness for Mankind—it follows that "the nature of man, and the good of society, are to us the reason and rule of moral good and evil." And this is an immutable foundation of morality, insofar as "man continues a rational and sociable creature," for the law of nature is the product of human nature itself, and consequently "it must subsist as long as human nature" (WCC I, 58). Thus, Sheridan suggests that the discrepancy between Trotter's view of morality and Locke’s is also "a mark of her intellectual independence.”23

\section{The Will of God}

According to Burnet, another dangerous consequence of Locke's account of morality is voluntarism. To be clear, the term was coined only in the nineteenth century, perhaps by the German sociologist Ferdinand Tönnies (1855-1936), to define a moral theory according to which will takes priority over intellect, and, as applied to divine action, voluntarism holds that morality originates from the will of God. Historically, this view is attributed to Augustine of Hippo, Duns Scotus, William of Ockham, and, in the early modern age, to Thomas Hobbes, and Robert Boyle. The opposite approach is usually called "intellectualism," according to which intellect takes precedence over will, and moral standards eternally exist in God's intellect, determining his will and command. This view is usually ascribed to Thomas Aquinas, in the middle age, and Cambridge Platonists, in the seventeenth century. ${ }^{24}$ Obviously, Thomas Burnet did not use the term, but accused Locke of grounding morality in the arbitrary divine will, explicitly referring to a well-known passage in Locke's Essay:

Good and evil... are nothing but pleasure or pain, or that which occasions or procures pleasure or pain to us. Moral good and evil then is only the conformity or disagreement of our voluntary actions to some law, whereby good or evil is drawn on us by the will and power of the law-maker; which good and evil, pleasure or pain, attending our observance, or breach of the law, by the decree of the law-maker, is that call reward and punishment. (Essay, II, 28, §5)

Elsewhere, Locke also maintained that the true ground of morality "can only be the will and law of God," who "has in his hand rewards and punishments" (Essay, I, 3, §6). Such a view was unacceptable for Burnet, who argued that, if the will of the law-maker is an arbitrary power and "has no rule to go by" (FR, 6), it follows that God himself "might be the author of sin," for there is no rule of sin to him, but "all things are indifferent, till he declare this or that to be sin, according to his pleasure" (SR, 22). There must necessarily be a rule determining his will, which states from eternity the difference between good and evil. And such a rule is the nature of God himself, insofar as he is understood not only as an all-powerful, all-knowing, and eternal being, but also as good and just. "If Goodness and Justice—Burnet said—belong to his essence, as well as those other perfections, a man may from the idea of God have a good foundation and support of his faith; and consequently 
of his virtue and piety. But without these, he is left in the dark, as to his fate, or future reward in another state" (TR, 6). It is noteworthy that if intellectualism states the priority of intellect over will, Burnet's anti-voluntarism was not purely intellectualist, for he held the priority of the nature of God, insofar as good and just, over his will.

Catharine Trotter rejected Burnet's accusation against Locke, by stressing that Locke himself had established morality upon "the nature of God and man," and that his notions of the "will of God" and "punishments and rewards" could "only give morality the force of a law," but they were not meant to be its true foundation. ${ }^{25}$ This was a central point in her vindication of Locke, which allowed her both to reject the charge of voluntarism, clarifying the role of the will and command of God in morality, and, at the same time, to emphasise the importance of human reason. Indeed, since "we can only know" the will of God "by its conformity to our nature" (WCC I, 62), his command would not have any effectiveness, if it were not "knowable to us by the light of nature" (WCC I, 61). In other words, according to Trotter, God's command is not the source of obligation, but we are obliged to do what he commands by our own reason.

In a lengthy footnote, added to her Defence in the 1751 edition, she pointed out that "the grounds of moral obligation are not here discussed at all; the notion of founding morality on arbitrary will is carefully rejected; and the nature of God, or the divine understanding, and the nature of man, all along supposed to be the true grounds of it” (WCC I, 61, nt. n). Trotter thought this sufficient to fulfil her purpose of defending Locke from Burnet's charge of voluntarism. Evidently, her criticism against the Remarker, on this point, did not concern contents - in fact she agreed with his dismissal of voluntarism — but it did concern his description of Locke as a voluntarist. Nevertheless, it is uncertain whether her own interpretation was fully consistent with Locke's moral approach. In her later works, especially those in defence of Samuel Clarke, Trotter explicitly entertained a sort of intellectualism. This is evident in her Remarks upon Some Writers, particularly in her comments on Edmund Law's argument against the best of possible worlds, ${ }^{26}$ where she stated that the will of God must "conform itself to reason, nature and fitness of things" (WCC I, 410). Furthermore, in another footnote appended to her Defence in 1751, she identified the original ground of morality with "the supreme mind, where all truth, and the abstract nature of all possible things, must eternally and immutably exist” (WCC I, 56, nt. f). However, like Burnet, she did not adopt a pure intellectualism. Particularly, in her Defence, there was no allusion either to God's intellect, or to eternal moral truths and laws determining his will. It seems to me that, in 1702, she was not actually concerned with God's action, but she was focused on morality from human perspective, and, unlike Burnet, she adopted a sort of moral anthropocentrism. In fact, as Bolton has noted, although Trotter confessed that moral obligation was not explicitly addressed in the Defence, she tacitly supposed that it "derives from human nature. ${ }^{27}$ Now, according to Trotter, such a nature is both reasonable and sociable, and also provides a sure foundation for natural religion. On this, she said the following:

It will not be much from the purpose here, to take notice of the folly of those men, who think to weaken the authority of religion, by calling it a politic contrivance, established for the good of government or society; which is as much as to say, it is the less obligatory, because it is necessary. Whereas that very thing shews it to be our indispensable duty, and of divine authority, without any revelation; since the divine workmanship, human nature, could not subsist without it. If they could prove it unpolitic or destructive to society, it would be much more for their purpose; for such a religion must necessarily be false; nothing can be a law to nature, which of direct consequence would destroy nature. (WCC I, 59)

By taking the good of society as "our indispensable duty, and of divine authority,” Trotter underlined that sociability is an intrinsic feature to human nature, as well as rationality, and we do not need "any revelation" to 
know this. Accordingly, rather than "weaken the authority of religion," sociability becomes the criterion of its truth, for an "unpolitic or destructive to society" religion must necessarily be false. Thus, it is plain that, by the time of her Defence, Trotter had already adopted an anti-voluntarist view, according to which the human nature lays the foundations of morality, and the will of God only gives it the force of a law. But, once considered her idea of human nature including both reason and sociability, I believe that her approach cannot be labelled as mere intellectualism.

\section{The Immortality of the Soul}

In the final part of his first Remarks, Burnet also expressed his perplexity about two of Locke's suppositions concerning the nature of the soul:

(1) Locke had firmly claimed that the soul may be sometimes absolutely without thoughts;

(2) He had not excluded the possibility of thinking matter.

The Remarker was seriously worried that these two suppositions endangered the immortality of the soul itself, and implied materialism and atheism.

As regards (1), Locke had argued that it is not "more necessary for the soul always to think, than for the body always to move," for thought is to the soul what motion is to the body: "not its essence, but one of its operations" (Essay, II, 1, §10). Furthermore, "that the soul always thinks" is not a self-evident proposition, but it needs proof and the support of experience. However, while experience itself infallibly shows that we sometimes think and, consequently, that there is a power of thinking in us, at the same time, it also shows that our cogitative activity is not continuous: for example, we do not think in sound sleep, or at least we have not consciousness of our thought while sleeping without dreaming. In fact, Locke believed it was "utterly inconsistent and impossible" to think without being conscious of it, because, paradoxically, "if it be possible that the soul can, whilst the body is sleeping, have its thinking... which the man is not conscious of nor partakes in, it is certain that Socrates asleep and Socrates awake is not the same person” (Essay, II, 1, §11). Thus, the identity of the person consists, according to Locke, in that consciousness which is essential to thinking, ${ }^{28}$ whereas to admit that the soul can think without consciousness implies that "soul" and "man" are two different persons, and that two men can share the same soul, which is absurd. ${ }^{29}$

Preliminarily, Burnet sarcastically emphasised how difficult it is for anyone to observe that his own soul sometimes does not think, for when one observes it, one actually thinks. ${ }^{30}$ Moreover, if a soul is "utterly without thoughts," he did not understand what can interrupt "that unthinking interval," and reactivate its cogitation (FR, 9). Indeed, if thought is to the soul what motion is to the body, as Locke argued, it follows that as a body in rest needs an external cause that "puts it into motion," so an unthinking soul needs a cause that "brings it to thoughts again" (FR, 10). Furthermore, he wondered what the soul is when it does not think; which "properties" distinguish it from nothing in sound sleep, when it has no thoughts; and "what security we can have, upon this supposition, that we shall not fall into this sleep at death” (FR, 9). Thus, Burnet's "great concern" was the apparent incompatibility between Locke's principles and the immortality of the soul:

Whether the soul be, or be not, a distinct substance from the body, I do not perceive that her immortality can be proved by your principles. If she be not distinct from the matter of the body, when that is corrupted and dissolved, it is manifest she must be dissolved also. And if she be a substance, distinct from matter, however you say she is sometimes without thoughts, or any manner of operation; why then may she not be so (according to this doctrine) after death, thoughtless and senseless, and so without life?... I know not how you explain that; nor how far you allow us to be the same men, and the same 
persons then that we are now... I know not how you conceive the Resurrection. But I confess I do not understand what that discourse about the identity or non-identity of the same man, sleeping and waking... what I say, it aims at and tends to. $(\mathrm{FR}, 12)$

For what concerns (2), i.e., the hypothesis of thinking matter, Locke had noted that this is far beyond the extent of our understanding, and revelation only can give us certainty about it. He thought it was highly probable that the thinking substance in us is immaterial, but, "in respect to our notion," he could not exclude that God has given "to some systems of matter fitly disposed a power to perceive and think" (Essay, IV, 3, §6). Burnet was really concerned with the materialist implications of such a hypothesis: "I’m afraid the materialists will profit too much from that notion or concession, that matter may think: for, say they, if matter be capable of thinking, it may have will and understanding, and any other faculty of a thinking substance, and in any degree of spiritual perfection, and consequently may be God" (FR, 13-14).

In his short and contemptuous Answer, Locke limited himself to referring the Remarker to his correspondence with Stillingfleet, who, despite having manifested similar worries about materialist resonances of empiricist epistemology, ${ }^{31}$ had also tried to give a demonstration of the immateriality of the soul, upon Locke's principles. ${ }^{32}$ Locke thought it sufficient to rebuff Burnet's criticisms, "but-he sardonically commented - if that will not serve his turn, I will tell him a principle of mine that will clear it to him; and that is, the revelation of life and immortality of Jesus Christ, through the gospel” (WJL III, 188).

Catharine Trotter examined and replied more carefully to Burnet's objections. Firstly, she noted that the supposition that "the soul always thinks" does not prove that it is immortal, and that "the contrary supposition takes not away any proof of it” (WCC I, 70). Therefore, Locke's hypothesis that men do not think in sound sleep does not weaken the immortality of the soul at all. Secondly, she charged her adversary of drawing groundless inferences from Locke's philosophy. In fact, Burnet intentionally misunderstood the aim of Locke's paradoxical supposition of two men sharing the same soul, and he arbitrarily concluded that Locke did not intend the soul as a permanent substance. ${ }^{33}$ Thirdly, Trotter imputed to the Remarker a loose use of language, especially when "he takes the soul, man, and person, to signify the same thing" (WCC I, 72), ignoring that for Locke these terms had different meanings: man was understood as the union of soul and body, and person as self-consciousness. Thus, she pointed out that personal identity consists "in the same consciousness, and not in the same substance: for whatever substance there is, without consciousness there is no person," and "wherever there are two distinct incommunicable consciousnesses, there are two distinct persons, though in the same substance" (WCC I, 73). According to Locke, indeed, the notion of substance, whether material or immaterial, is beyond our intellectual capabilities, and, therefore, it is not a sure foundation for personal identity. Moreover, without consciousness substance is but a "carcase," which cannot "unite remote existences into the same person" (Essay, II, 27, §23), and, in the case of an interruption of consciousness, such as amnesia or sound sleep, the same substance could host different selves.

Proceeding to Burnet's second difficulty, i.e., what produces a new thought, at the end of an unthinking interval, Trotter noted that there are several operations in the soul whose causes are unknown to us, such as "how it passes from one thought to another," or how it preserves all its ideas and can "recollect those it had not in a long time reflected on" (WCC I, 75), and, nonetheless, we are not sceptical of them. Burnet also worried that, upon Locke's principles, we could have a new soul every morning: "If a body cease to move, and come to perfect rest, the motion it had cannot be restored, but a new motion may be produced. If all cogitation be extinct, 
all our ideas are extinct, so far as they are cogitations, and seated in the soul: so we must have them new imprest, we are, as it were, new born and begin the world again” (SR, 17).

Trotter simply noted that, as everybody continues with its existence when motion ceases, and it is always the same body, when a new motion is produced, so the soul exists even during an unthinking sleep, and it is the same soul, when it wakes up, unless the Remarker proves—she said-“that every new motion makes, or seems to make a new body" (WCC I, 76). She also stressed that we can have no certain knowledge of the nature of the soul, of which we have only an idea formed upon its operations. However, we ignore whether it has "peculiar properties, whereby it is distinguished from other substances... and from matter," and, therefore, "if the soul has no essential properties distinct from matter, whereby she alone is capable of the power of thinking, there can be no reason, why matter may not have that power" (WCC I, 80). Trotter clearly adhered to Locke's agnosticism regarding substantial dualism, according to which we can only know the qualities of a substance, but not its substratum, ${ }^{34}$ for "we have no idea of what it is, but only a confused obscure one of what it does" (Essay, II, 13, §19). Since we do not know whether there is an ontological and substantial difference between thinking and unthinking beings, we also ignore whether the substratum, which supports thought, is material or immaterial. Nevertheless, as Trotter pointed out, Locke believed it was highly probable that the soul is immaterial, although he had no proof of it, and "it is not impossible, for anything we know, that God may give, or have given, to some systems of matter, disposed as he sees fit, a power to perceive and think” (WCC I, 87).

Moreover, Trotter thought that making the immateriality of the soul the main proof of its immortality had dangerous consequences for morality,

for this is an argument of no use to the generality of mankind, who want either leisure, or capacity, for such nice speculations; and if they are convinced on other grounds, that the soul is immortal, it is no great matter, whether they think it immaterial, or no. But if they are persuaded, that it cannot be immortal, if it is not immaterial, it is easy to see of how ill consequence that must be, if the proofs of the soul's immateriality should not happen to convince them. (WCC I, 84)

Interestingly, she showed that Burnet's arguments were not real difficulties for Locke, placing the burden of proof on Burnet himself, who had to demonstrate both that thinking substances are immaterial only and that they are never without thought, even in sound sleep. Furthermore, Trotter stressed that Locke's theory of personal identity was perfectly consistent with the Christian doctrine of resurrection. In fact, consciousness only "makes the same person and constitutes this inseparable self" (Essay, II, 27, §17), and, since "in this personal identity is founded all the right and justice of reward and punishment” (Essay, II, 27, §18), it follows that

we may be able, without any difficulty, to conceive the same person at the resurrection, though in a body not exactly in make or parts the same which he had here, the same consciousness going along with the soul that inhabits it. But yet the soul alone in the change of bodies, would scarce to anyone, but to him that makes the soul the man, be enough to make the same man. (Essay, II, 27, §15)

According to Trotter, this was sufficient to show that Locke's doctrine of the soul was consistent with Revelation, ${ }^{35}$ and that he did not embrace any sort of Deism, according to which "there is one infinite, universal spirit, that actuates matter always," without "the operations of particular spirits, distinct from the universal” (TR, 23). On the contrary, Locke supposed that the soul is actually a distinct permanent substance, even in the case it were material, "for a material substance is not less a substance than an immaterial" (WCC I, 109). From Trotter point of view, Burnet erroneously identified a material substance with a body, drawing the 
unnecessary conclusion that the soul cannot exist after the dissolution of the body. "But—she concluded—that one, who thinks God may have given perception and thought to some systems of matter disposed as he sees fit, may suppose this system distinct from the body; and to continue in the same state of cogitation, when the body is dissolved" (WCC I, 110).

Locke's doctrine of personal identity has been the subject of a long and still open debate, which can be traced back to the bishop Edmund Law (1703-1787), who offered a mode-based interpretation of Locke's view on person. ${ }^{36}$ According to Gordon-Roth, it is not clear whether Trotter entertained a substance or mode reading of Locke's theory of personal identity. It is worth noting that the debate was not in place by the time she wrote her Defence, and, obviously, she had no reasons to express a clear position about the ontology of person. However, there are clues that, over sixty years before Law, she advocated a mode reading of Locke's notion of person, especially in the following:

... personal identity, according to him [Locke], consisting in the same consciousness, and not in the same substance: for whatever substance there is, without consciousness there is no person. Consciousness therefore, and not substance, making a person, the same consciousness must make the same person, whether in the same, or in different substances; and no farther than the same consciousness extends, can there be the same person: but wherever there are two distinct incommunicable consciousnesses, there are two distinct persons, though in the same substance. (WCC I, 73)

\section{Conclusion}

Trotter's Defence of Mr. Locke's Essay offers an excellent overview on some of the most controversial points of Locke's masterpiece, especially concerning morality. By following Burnet's criticisms, she showed that the moral consequences of Locke's epistemology were perfectly consistent with Christian religion, and did not fall into atheism, materialism or deism, despite his adversary's worries. Nevertheless, the Defence was much more than a mere vindication, and Trotter herewith manifested an extraordinary acumen in many respects.

Firstly, in presenting Burnet's objections she was accurate and faithful to his text. Without altering the Remarker's discourse to her own advantage, she simply highlighted its inconsistencies, mistaken inferences, and loose language. Moreover, she showed that his remarks were often grounded on a misinterpretation of Locke's philosophy, and more problematic than those principles of Locke's he criticised.

Secondly, the ideas she presented-along with her apology of Locke-appear original, albeit not new. According to Victor Nuovo, there is a difference between philosophical originality and novelty, and, even though there is nothing new in Trotter's writings, her "authority” and "clarity” make her ideas original. ${ }^{37}$ Emily Thomas goes farther and argues that there is novelty in Trotter's discourse, especially in her account of "substantival space."38 It seems to me that she was very familiar with the main philosophical issues of her time, and, consequently, she was able to oppose interesting objections to Burnet's remarks, and, at the same time, to propose strong alternative solutions to the problems he raised. This is particularly evident when she showed that Burnet's concept of natural conscience was misleading and a very unsure foundation for morality. On the contrary, by stressing the rationality and sociability of human nature, she strongly affirmed an anthropocentric foundation of morality. Moreover, when rebuffing Burnet's accusation of voluntarism against Locke, she argued that God's will and command have the force of a law insofar as human beings can know it by their conformity to human reason. Finally, by defending Locke's account of personal identity, she offered an original mode-based interpretation of it. 
To conclude, despite the 17th-century bias against female intellectual skills, Catharine Trotter's Defence of John Locke was not a mere apology of that eminent thinker, but it was an active and original contribution to the early modern philosophical discourse.

\section{Notes}

1. However, the traditional attribution to Thomas Burnet has been recently put into question (J. C. Walmsley, H. Craig, and J. Burrows 2016).

2. First of all, John Locke sent her a gift of books along with his letter of thanks (WCC I, XX). John Toland defined her as an "absolute mistress of the most abstracted speculations in the metaphysics, who with an easy turn of style and argument has defended Mr. Locke's Essay of Human Understanding against the letters of an eminent divine” (Toland 1704, Preface, §6). She was also appreciated by Gottfried W. Leibniz (GP III, 308; V, 63).

3. Although Trotter died in 1749, and The Works were published in 1751, the project of this edition started while she was still alive, and some corrections and explanatory footnotes show that she and her family were directly involved in the project (Kelley 2002, 2). It is worth noting that Trotter eventually decided to come out, even though she was almost seventy years old. This reveals, I believe, that her contribution to the philosophical discourse was broadly acknowledged towards the mid-eighteen century, against any gender prejudice.

4. O’Neill 2005.

5. Waithe 1991; Brandt Bolton 1993; Hutton 1998; Broad 2002; Kelley 2001, 2002; Ready 2002; Sheridan 2007; Mocchi 2010; Nuovo 2011; Myers 2012; Duran 2013; Sund 2013; Thomas 2013, 2015; Gordon-Roth 2015; De Tommaso-Mocchi 2016; De Tommaso 2017.

6. Gordon-Roth 2015, 65-66.

7. See, for example, her letters to Thomas Burnet of Kemnay (WCC II, 153-207), those to her niece, Anne Hepburn (WCC II, 255-346), and those to Rev. Dr. Thomas Sharp (WCC II, 355; 373-4).

8. "I am more afraid—she wrote to Burnet of Kemnay—of appearing before him I defend, than of the public censure; and chiefly for the honour I bear to him, resolve to conceal myself” (WCC II, 155).

9. WCC I, 53; 65.

10. This would be coherent to the attribution of the Remarks to Thomas Burnet, who, in fact, had been a pupil of John Tillotson (later Archbishop of Canterbury) at Clare Hall, Cambridge. At that time, Ralph Cudworth was Master of that college, and when, in 1654, he moved to Christ's College as Master, Burnet followed him and later became a fellow of the same college.

11. Cudworth 1996, 174. Although the Treatise would not have been published until 1838, it is not unlikely that Burnet privately discussed this point with Cudworth, whom he was acquainted with.

12. More 1655, I, V, 19-20.

13. Ibid., I, III, §§7-8, 17.

14. According to S. A. Grave, Burnet in some way seems to have anticipated Shaftesbury's theory of Moral-Sense, later developed by Francis Hutchenson (1694-1746) and Joseph Butler (1692-1752) (Grave 1981, 10-17; Tuveson 1948).

15. In a long footnote, added in the posthumous edition of her Works, and in all likelihood written by Trotter herself, she confessed some rethinking about this point. The whole paragraph was described as a partial consideration of moral truths, "with relation only to the present constitution of things, not to their original ground, as they exist eternally in the divine mind" (WCC I, 56, nt. f.). According to Martha Brandt Bolton, in her mature works, Trotter distanced herself from some "roughly Lockean views," and openly endorsed a more Platonist metaphysics, probably inspired by Samuel Clarke (Brandt Bolton 1993, 570). I subscribe to Bolton's interpretation, and I also believe that, later in her life, Trotter entertained an ethical rationalism, which never recanted Lockean epistemology, albeit inspired by Cambridge Platonism. Due to space limitation, I will not herewith deepen this point, which is beyond the purpose of this paper, but I will limit myself to noting that Trotter's late rethinking did not undermine her early vindication of John Locke, especially for what concerns the true grounds of morality, which she identified with human nature (De Tommaso 2017, 29-33).

16. With respect to this, Trotter clearly embraced Locke's Empiricist doctrine without reservation: "we call good-he had written in his Essay - which is apt to cause or increase pleasure, or diminish pain in us... and, on the contrary, we name that evil, which is apt to produce or increase any pain, or diminish any pleasure in us” (Essay, II, 20, §2).

17. Essay, IV, 10, §§1-19.

18. Sheridan $2007,134$.

19. Locke 1954, 109.

20. Ibid., 111.

21. Ibid., 199. Nevertheless, Locke's view on the grounds of the law of nature is controversial and still under debate (Oakley-Urdang 1966; Simmons 1992, 32-36; Tuckness 1999; Sheridan 2007, 139-40; Forde 2011).

22. Sheridan 2007,147 
23. Sheridan 2007, 134. I do not disagree with Sheridan on Trotter's intellectual autonomy, however, I have some perplexities about her reading Locke's Essays on the Law of Nature, which were still unpublished by the time she wrote her Defence. In fact, the Essays are a number of early writings in Latin, collected, translated in English, and published by W. Von Leyden only in 1954.

24. For a detailed overview of the origins of voluntarism and intellectualism in Ethics see Schneewind 1998, 17-36. See also Korkman 2003.

25. WCC I, 60-61.

26. Trotter commented Law's notes included in his English translation of William King's De Origine Mali (WCC I, 402-16).

27. Bolton 1993, 574.

28. He defined a person as "a thinking intelligent being, that has reason and reflection, and can consider itself as itself, the same thinking thing in different times and places; which it does only by that consciousness which is inseparable from thinking, and, as it seem to me, essential to it: it being impossible for anyone to perceive, without perceiving that he does perceive" (Essay, II, 27, §9).

29. Essay, II, 1, §12.

30. FR, 8.

31. Stillingfleet $1697,54-55$.

32. Ibid., 69-83.

33. SR, 15.

34. "By putting together the ideas of thinking, perceiving, liberty, and power of moving themselves, and other things, we have as clear a perception and notion of immaterial substances, as we have of material... Our idea of substance is equally obscure, or none at all in both: it is but a supposed I know not what, to support those ideas we call accidents” (Essay, II, 23, §15).

35. "The Remarker must be contented to walk in the dark as to these things, though he says he does not love it, since there is no way to have farther light in them than the Scripture has given” (WCC I, 86).

36. Law 1769. The principal contemporary proponents of this reading are Ruth Mattern (1980), William Uzgalis (1990) Antonia Lolordo (2010; 2012), and Galen Strawson (2011).

37. Nuovo 2011, 248-9.

38. Thomas 2013; 2015.

\section{Works Cited}

Brandt Bolton, Martha. “Some Aspects of the Philosophy of Catharine Trotter.” Journal of the History of Philosophy 31.4 (1993): 565-88.

Broad, Jacqueline. Women Philosophers of Seventeenth Century. Cambridge: Cambridge University Press, 2002. 141-65.

Cudworth, Ralph. A Treatise Concerning Eternal and Immutable Morality-A Treatise of Freewill. Ed. S. Hutton. Cambridge: Cambridge UP, 1996.

De Tommaso, Emilio M. “Il razionalismo etico di Catharine Trotter Cockburn.” Intersezioni 37.1 (2017): 19-38.

De Tommaso, E. M. and Mocchi, G. “Catharine Trotter, una filosofa in età moderna.” Trotter Cockburn 2016: 9-70.

Duran, Jane. “Early English Empiricism and the Work of Catharine Trotter Cockburn.” Metaphilosophy 44 (2013): 485-94.

Forde, Steven. “'Mixed Modes’ in John Locke’s Moral and Political Philosophy.” The Review of Politics 73 (2011): 581-608.

Gordon-Roth, Jessica. “Catharine Trotter Cockburn’s Defence of Locke.” The Monist 98 (2015): 64-76.

Grave, Selwyn A. Locke and Burnet. Perth: Philosophy Society of W. A. and Department of Philosophy, University of Western Australia, 1981.

Hutton, Sarah. “Cockburn, Catharine (1679-1749).” Ed. Craig Edward. Routledge Encyclopaedia of Philosophy. Routledge: London, 1998. <https://www.rep.routledge.com/articles/cockburn-catharine-1679-1749>.

Kelley, Anne. Catharine Trotter. An Early Modern Writer in the Vanguard of Feminism. Aldershot: Ashgate, 2002.

---. “'In Search of Truths Sublime': Reason and the Body in the Writings of Catharine Trotter.” Women's Writing 8.2 (2001): 235-50.

Korkman, Petter. "Voluntarism and Moral Obligation: Barbeyrac's Defence of Pufendorf Revisited.” Eds. Hochstrasser, T. and Schröder P. Early Modern Natural Law Theories: Contexts and Strategies in the Early Enlightenment. Dordrecht: Kluwer, 2003. 195-225.

Law, Edmund. Defence of Mr. Locke’s Opinion Concerning Personal Identity. Cambridge: J. Johnson \& Co., 1769.

Locke, John. Essay on the Law of Nature. Ed. W. von Leyden. Oxford: Clarendon Press, 1954.

Lolordo, Antonia. “Person, Substance, Mode and ‘the Moral Man' in Locke’s Philosophy.” Canadian Journal of Philosophy 40.4 (2010): 643-67.

---. Locke’s Moral Man. Oxford: Oxford University Press, 2012.

Mattern, Ruth. “Moral Science and the Concept of Persons in Locke.” The Philosophical Review 89.1 (1980): 24-45. 
Mocchi, Giuliana. "L’obbligazione morale in Catharine Trotter.” Eds. Bufalo, R., et al. Natura Storia Società. Milano: Mimesis, 2010. 717-29.

More, Henry. An Antidote against Atheism, or, an Appeal to the Natural Faculties of the Mind of Man, Whether There Be Not a God. 2nd ed. London: Flesher, 1655.

---. An Account of Virtue: Or Dr. Henry More's Abridgement of Morals. London: Tooke, 1690.

Myers, Joanne E. “Catharine Trotter and the Claims of Conscience.” Tulsa Studies in Women's Literature 31.1/2 (2012): 53-75.

Nuovo, Victor. Christianity, Antiquity, and Enlightenment. Interpretations of Locke. Dordrecht-Heidelberg-London-New York: Springer, 2011.

Oakley, Francis and Urdang, Elliot W. “Locke, Natural Law, and God; Note.” Natural Law Forum 1966: 92-109.

O’Neill, Eileen. "Early Modern Women Philosophers and the History of Philosophy.” Hypatia 20.3 (2005): 185-97.

Ready, Kathryn J. "Damaris Cudworth Masham, Catharine Trotter Cockburn, and the Feminist Legacy of Locke’s Theory of Personal Identity.” Eighteenth-Century Studies 35.4 (2002): 563-76.

Schneewind, Jerome B. The Invention of Autonomy: A History of Modern Moral Philosophy. Cambridge: Cambridge UP, 1998.

Sheridan, Patricia. "Reflection, Nature, and Moral Law: The Extent of Catharine Cockburn's Lockeanism in Her Defense of Mr. Locke’s Essay.” Hypatia 22.3 (2007): 133-51.

Simmons, A. John. The Lockean Theory of Rights. Princeton: Princeton UP, 1992.

Stillingfleet, Edward. The Bishop of Worcester's Answer to Mr. Locke's Letter Concerning Some Passages Relating to His Essay of Humane Understanding: Mentioned in the Late Discourse in Vindication of the Trinity, with a Postscript in Answer to Some Reflections Made on That Treatise in a Late Socinian Pamphlet. London: Mortlock, 1697.

Strawson, Galen. Locke on Personal Identity. Princeton: Princeton University Press, 2011.

Sund, Elizabeth. “The Right to Resist: Women’s Citizenship in Catharine Trotter Cockburn's The Revolution of Sweden.” Eds. Curtis-Wendlandt, L., et al. Political Ideas of Enlightenment Women: Virtue and Citizenship. New York: Ashgate, 2013. 141-56.

Thomas, Emily. “Catharine Cockburn on Substantival Space.” History of Philosophy Quarterly 30.3 (2013): 195-2014.

---. "Catharine Cockburn on Unthinking Immaterial Substance: Souls, Space, and Related Matters.” Philosophy Compass 10.4 (2015): 255-63.

Toland, John. Letters to Serena. London: Lintot, 1704.

Trotter Cockburn, Catharine. Difesa del Saggio sull'intelletto umano del sig. Locke. Eds. Emilio M. De Tommaso and Giuliana Mocchi. Lugano: Agorà, 2016.

Tuckness, Alex. “The Coherence of a Mind: John Locke and the Law of Nature.” Journal of the History of Philosophy 37.1 (1999): 73-90.

Tuveson, Ernest. “The Origins of the 'Moral Sense.”” Huntington Library Quarterly 11.3 (1948): 241-59.

Uzgalis, William. "Relative Identity and Locke’s Principle of Individuation.” History of Philosophy Quarterly 7 (1990): $283-97$.

Walmsley, J. C., Craig, H., and Burrows, J. "The Authorship of the Remarks upon an Essay of Humane Understanding.” Eighteenth-Century Thought 6 (2016): 205-43.

Waithe, Mary Ellen. “Catharine Trotter Cockburn.” Ed. Waithe, M. E. A History of Women Philosophers, Vol. III. Modern Women Philosophers, 1600-1900. Dordrecht: Kluwer Academic Publishers, 1991. 101-25.

List of Abbreviations

GP_Gottfried W. Leibniz. Die Philosophischen Schriften. Ed. Carl I. Gerhardt. 7 voll. (Berlin 1875-90), Hildesheim: G. Olms, 1965.

Essay_Locke, John. An Essay Concerning Human Understanding. WJL I-II.

FR-Thomas Burnet. Remarks upon an Essay Concerning Humane Understanding. In a Letter addres'd to the Author. London: Wotton, 1697.

SR-Thomas Burnet. Second Remarks upon an Essay Concerning Humane Understanding. In a Letter addres'd to the Author. London: Wotton, 1697.

TR-Thomas Burnet. Third Remarks upon an Essay Concerning Humane Understanding. In a Letter addres'd to the Author. London: Wotton, 1699.

WCC-The Works of Mrs. Cockburn, Theological, Moral, Dramatic, and Poetical, Several of Them First Printed, Revised and Published with an account of the life of the author by Thomas Birch, 2 vols. London: J. and P. Knapton, 1751.

WJL-The Works of John Locke in Nine Volumes, London: Rivington, 1824. Aalen: Scientia Verlag, 1963. 